Response to : 'Domestic use of bleach and infections in children: a multicentre cross-sectional study' Response

Casas, Lidia

2016-03

Casas , L , Espinosa , A , Borras-Santos , A , Jacobs , J , Krop , E , Heederik , D , Nemery , B , Pekkanen , J , Hyvarinen , A , Taubel , M \& Zock, J-P 2016 , ' Response to : 'Domestic use of bleach and infections in children: a multicentre cross-sectional study' Response ', Occupational and Environmental Medicine , vol. 73 , no. 3 , pp. 215-216 . https://doi.org/10.1136/oemed-2015-10325

http://hdl.handle.net/10138/161383

https://doi.org/10.1136/oemed-2015-103255

publishedVersion

Downloaded from Helda, University of Helsinki institutional repository.

This is an electronic reprint of the original article.

This reprint may differ from the original in pagination and typographic detail.

Please cite the original version. 


\title{
Clinicopathological characteristics and cell cycle proteins as potential prognostic factors in myoepithelial carcinoma of salivary glands
}

\author{
F. Passador-Santos ${ }^{1,2} \cdot$ M. Grönroos ${ }^{1} \cdot$ J. Irish $^{3} \cdot$ R. Gilbert ${ }^{3} \cdot$ P. Gullane ${ }^{3}$. \\ B. Perez-Ordonez ${ }^{4}$ A. Mäkitie ${ }^{5,6} \cdot$ I. Leivo ${ }^{7,1}$
}

Received: 18 June 2015 /Revised: 17 October 2015 / Accepted: 23 November 2015 / Published online: 28 December 2015

(C) Springer-Verlag Berlin Heidelberg 2015

\begin{abstract}
Myoepithelial carcinoma (MCA) is a rare malignancy of salivary glands that was included in the WHO Classification of Head and Neck Tumors in 1991. MCA has shown a broad spectrum of clinical outcomes, but attempts to identify prognostic markers for this malignancy have not resulted in significant progress. Conventional histopathological characteristics such as tumour grade, nuclear atypia, mitotic index and cell proliferation have failed to predict the outcome of MCA. In this study, we reviewed the histopathology of 19 cases of MCA focusing on nuclear atypia, mitotic count, tumour necrosis, nerve and vascular invasion and occurrence of a pre-existing pleomorphic adenoma in connection to the MCA. Histopathological characteristics and clinical information were correlated with the immunohistochemical
\end{abstract}

F. Passador-Santos

passadorio@gmail.com

1 Department of Pathology, Haartman Institute, University of Helsinki, P.O. Box 21, Haartmaninkatu 3, FIN-00014 Helsinki, Finland

2 Department of Pathology, São Leopoldo Mandic Research Centre, Campinas, Brazil

3 Department of Otolaryngology and Surgical Oncology, University of Toronto, Toronto, ON M5S, Canada

4 Department of Pathology, University of Toronto, Toronto, ON M5S, Canada

5 Department of Otorhinolaryngology - Head and Neck Surgery, University of Helsinki and Helsinki University Hospital, P.O. Box 220, FI-00029 HUS Helsinki, Finland

6 Division of Ear, Nose and Throat Diseases, Department of Clinical Sciences, Intervention and Technology, Karolinska Institutet, Karolinska University Hospital, SE-171 77 Stockholm, Sweden

7 Department of Pathology, University of Turku, Kiinamyllynkatu 10, 20520 Turku, Finland expression of cell cycle proteins including c-Myc, p21, Cdk4 and Cyclin D3. The proportion of tumour cells immunoreactive for these markers and their intensity of staining were correlated with clinical information using logistic regression, Kaplan-Meier and Cox regression. Using logistic regression analysis, cytoplasmic c-Myc expression was associated with the occurrence of metastases $(P=0.019)$, but limitations of semi-quantitation of immunostaining and the limited number of cases preclude definitive conclusions. Our data show that the occurrence of tumour necrosis predicts poor diseasefree survival in MCA $(P=0.035)$.

Keywords Myoepithelial carcinoma $\cdot$ Salivary gland $\cdot$ Cell cycle proteins $\cdot$ Immunohistochemistry $\cdot$ Head and neck cancer

\section{Introduction}

Myoepithelial carcinoma (MCA) of salivary glands comprises less than $2 \%$ of salivary gland carcinomas. These malignancies are almost exclusively composed of cells with myoepithelial differentiation. They arise de novo or develop in a pre-existing pleomorphic adenoma or benign myoepithelioma (benign myoepithelial adenoma) [1]. MCA represents the malignant counterpart of benign myoepithelioma, the differential diagnosis being based predominantly on the presence or absence of invasive growth. MCA is a well-established malignancy but its clinical behaviour varies [1-5], and attempts to identify clinically useful indicators of MCA prognosis have not been successful.

The cell cycle comprises a complex array of proteins, which interact to control cell proliferation. Regulation of expression of genes encoding cell cycle proteins includes activity of checkpoint proteins such as cyclins and cyclin-dependent kinases, which ensure that the cell divides only after errors occurred 
during replication of the genome have been corrected. If not, the cell is kept in a senescent state or will undergo apoptosis [6]. Disruptions in a variety of cell cycle regulators have been reported in cancer. The significance of aberrations in checkpoint proteins seems to depend on the context in which they occur. The histogenesis and genetic and epigenetic alterations in any particular malignancy play an important role in how cell cycle aberrations affect tumour behaviour [7].

Some of the key proteins in cell cycle regulation include cmyc, p21, Cdk4 and Cyclin D3. MYC gene encodes a nuclear phosphoprotein that serves as a DNA-binding factor activating or repressing the transcription of a large number of genes [8]. Furthermore, MYC regulates many cellular processes including chromatin structure, mRNA translation, DNA replication and biogenesis of ribosomes [9]. In many cancers, $M Y C$ aberrations lead to its constitutive activation [8]. Of the many target genes of MYC, CDK4 and CYCLIN D1 have important roles in the cell cycle. Both of them phosphorylate $R B$, leading to cell cycle progression and enhanced proliferation [6]. In addition, $M Y C$ may downregulate $\mathrm{CDK}$ inhibitors such as $P 15, P 21$ and $P 27$, which contributes to cell cycle progression in early and mid-G1 $[6,10]$..

In an attempt to identify prognostic factors for MCA, we reviewed the clinical and histopathological characteristics of 19 MCAs and studied expression of cell cycle proteins.

\section{Materials and methods}

Nineteen cases of MCA were retrieved from the files of the Department of Pathology, University of Helsinki, Helsinki, Finland (eight cases) and four from other hospitals in Finland and Toronto General Hospital, University Health Network, Toronto, Canada (seven cases). All cases fulfilled the diagnostic histopathological criteria of MCA according to the WHO Classification of Head and Neck Tumours (2005). In addition, the diagnoses were confirmed by immunohistochemistry using a panel of markers for myoepithelial differentiation (calponin, alpha-smooth muscle actin, smooth muscle myosin heavy chain, p63, CD10, CK14). Pure myoepithelial differentiation was unequivocally identified in all cases. Tumour infiltration into adjacent salivary gland and/or other tissues was the criterion confirming malignancy.

Clinical data and follow-up information were obtained from hospital records. Tissue sections $(5 \mu \mathrm{m})$ were deparaffinized and subjected to microwave-induced epitope retrieval in $0.01 \mathrm{M}$ citrate buffer (pH 6.0) for $20 \mathrm{~min}$. The specimens were then incubated in a solution of $3 \%$ hydrogen peroxide in methanol to block endogenous peroxidase. For staining with monoclonal antibodies, the avidin-biotin-peroxidase complex technique (Vectastain ${ }^{\circledR}$, Vector laboratories) was used. For staining with polyclonal antibodies, a dextran polymer conjugated two-step visualization system was used (Envision ${ }^{\circledR}$, Dako). Sections were incubated with the antibodies overnight at $+4{ }^{\circ} \mathrm{C}$ (Table 1). Positive controls for each antibody were used as suggested by their suppliers. Negative controls were obtained by replacing the primary antibody with the DAKO REAL ${ }^{\circledR}$ diluent. Aminoethylcarbazole was used as chromogen. The sections were counterstained with Mayer's haematoxylin and visualized using a Nikon D80 light microscope.

The intensity of the immunoreactivity was scored semiquantitatively as negative (0), weak (1) and strong staining (2). In addition, the extent of staining for $\mathrm{p} 21$ and Cdk4 was scored. For p21, if fewer than $10 \%$ of the nuclei were positive, the sample was scored as 1 , and if more than $10 \%$ of the nuclei were positive, the score was 2 . For Cdk4, if fewer than $50 \%$ of the nuclei were positive, the score was 1 , and if over $50 \%$ of the nuclei were positive, the score was 2 .

The results were analysed using logistic regression, Kaplan-Meier and Cox regression. The variables included intensity of cytoplasmic staining for c-Myc; intensity of nuclear staining for c-Myc; intensity of staining for Cyclin D3, p21 and Cdk4; extent of staining for p21 and Cdk4 and index of staining for $\mathrm{p} 21$ and Cdk4. These parameters were correlated with tumour size, TNM stage, primary or secondary nature of the tumour and the presence or absence of metastases. The clinical data of the patient at last follow-up were used as the endpoint. In Kaplan-Meyer analysis, the follow-up times were used for survival analysis.

A literature search for clinicopathological series of MCA was carried out in PubMed. The five largest series with altogether 144 cases of MCA with clinical and histopathological data were used as reference for our study (Table 2). We considered the diagnostic terms myoepithelial carcinoma and malignant myoepithelioma as synonyms. These published cases were studied in order to compare outcome of patients with MCA expleomorphic adenoma and de novo MCA. Metastases and recurrences were used as parameters of clinical outcome.

\section{Results}

\section{Clinical information}

The clinical data are summarized in Table 2. There were nine male and ten female patients with a mean age of 54.9 years

Table 1 Antibodies

\begin{tabular}{llll}
\hline Antibody & Clonality & Dilution, titer 1 & Source \\
\hline c-myc & Monoclonal & 150 & BD \\
p21 & Monoclonal & 50 & Calbiochem \\
Cdk4 & Polyclonal & 700 & Santa Cruz \\
& & & Biotechnology \\
Cyclin D3 & Monoclonal & 100 & Vector \\
\hline
\end{tabular}


Table 2 Clinical information

\begin{tabular}{|c|c|c|c|c|c|c|c|}
\hline $\begin{array}{l}\text { Case } \\
\text { no. }\end{array}$ & $\begin{array}{l}\text { Age } \\
\text { (years)/ } \\
\text { sex }\end{array}$ & $\begin{array}{l}\text { Primary } \\
\text { site }\end{array}$ & TNM & Treatment & Recurrence & Metastases & $\begin{array}{l}\text { Follow- } \\
\text { up } \\
\text { (months) }\end{array}$ \\
\hline 1 & $57 / \mathrm{M}$ & SUB & T1N0M0 & Sx, RT & Yes & Yes, lungs & 42 \\
\hline 2 & $67 / \mathrm{M}$ & $\mathrm{P}$ & T1N0M0 & Sx, ND & No & No & 3 \\
\hline 3 & $55 / \mathrm{F}$ & SUB & T1N0M0 & $\mathrm{Sx}, \mathrm{ND}, \mathrm{RT}$ & No & No & 23 \\
\hline 4 & $28 / \mathrm{M}$ & $\mathrm{P}$ & T1N0M0 & Sx, ND & No & No & 17 \\
\hline 5 & $61 / \mathrm{M}$ & $\mathrm{UL}+\mathrm{CH}$ & T2N0M0 & $\mathrm{Sx}, \mathrm{ND}$ & No & No & 31 \\
\hline 6 & $55 / \mathrm{F}$ & $\mathrm{P}$ & T1N0M0 & $\mathrm{Sx}, \mathrm{ND}, \mathrm{RT}, \mathrm{CT}$ & Yes & Yes, lungs & 31 \\
\hline 7 & $30 / \mathrm{M}$ & $\mathrm{P}$ & T2N0M0 & Sx & No & No & 82 \\
\hline 8 & $51 / \mathrm{F}$ & $\mathrm{P}$ & T3N0M0 & Sx, ND & No & No & 9 \\
\hline 9 & $67 / F$ & $\mathrm{P}$ & T2N0M0 & $\mathrm{Sx}, \mathrm{ND}$ & No & No & 2 \\
\hline 10 & $71 / \mathrm{M}$ & $\mathrm{P}$ & T4N0M0 & $\mathrm{Sx}, \mathrm{ND}, \mathrm{RT}$ & Yes & No & 12 \\
\hline 11 & $60 / \mathrm{M}$ & $\mathrm{P}$ & T2N0M0 & $\mathrm{Sx}, \mathrm{ND}, \mathrm{RT}$ & No & No & 21 \\
\hline 12 & $68 / \mathrm{F}$ & SUB & T2N0M0 & Sx, RT & Yes & No & 47 \\
\hline 13 & $78 / \mathrm{F}$ & $\mathrm{HP}$ & T1N0M0 & Sx & No & No & 19 \\
\hline 14 & $43 / F$ & $\mathrm{HP}$ & T1N0M0 & Sx & No & No & 63 \\
\hline 15 & $62 / \mathrm{M}$ & SUB & T2N0M0 & Sx & No & No & 84 \\
\hline 16 & $70 / \mathrm{F}$ & $\mathrm{P}$ & T4aN0M0 & $\mathrm{Sx}, \mathrm{ND}, \mathrm{RT}$ & Yes & Yes, multiple & 5 \\
\hline 17 & $28 / \mathrm{F}$ & $\mathrm{P}$ & T4N0M0 & Sx & Yes & No & 164 \\
\hline 18 & $52 / \mathrm{M}$ & $\mathrm{P}$ & T1N0M0 & Sx, RT & Yes & Yes, multiple & 26 \\
\hline 19 & $41 / F$ & $\mathrm{P}$ & T4aN0M0 & Sx, RT & No & No & 178 \\
\hline
\end{tabular}

$P$ parotid, $S U B$ submandibular gland, $H P$ hard palate, $U L+C H$ upper lip + cheek, $T B$ tongue base

(range 28 to 78 years). MCA was localized in 12 patients in the parotid gland, in four in the submandibular gland, in two in the hard palate and in one in the buccal mucosa. Of the cases, 12 were de novo MCAs and seven were MCAs ex-pleomorphic adenoma. Tumour size varied from less than $2 \mathrm{~cm}$ to more than $4 \mathrm{~cm}$. At the time of diagnosis, none of the patients showed metastases. All MCAs were removed surgically, and ten patients received postoperative radiotherapy, while one patient had also chemotherapy. Follow-up information was available for 12 cases (mean 50.7 months, range 2 to 178 months). Of the patients, seven presented with a recurrence of the primary tumour, and four had metastatic disease. At the end of follow-up, three patients had died of the disease and 15 were alive without evidence of disease. Of the four patients with metastatic disease, two had MCA ex-pleomorphic adenoma as primary tumour.

\section{Histopathological features}

Two basic growth patterns were seen: a multinodular pattern and a diffuse sheet-like pattern. The multinodular growth pattern was more prevalent (Fig. 1a). Several cell types were observed in MCAs, and a mixture of two cell types with one being more prevalent was seen in almost all tumours. Most MCAs contained the epithelioid cell type (eight cases) (Fig. 1b). A mostly clear cell type was found in three tumours (Fig. 1c) while two were mostly plasmacytoid (Fig. 1d) and four others showed a mostly spindle cell type (Fig. 1e). Two MCAs contained more than two cell types, none of which predominated. Most of the tumours presented some nuclear pleomorphism, while five cases showed marked nuclear atypia. Only one case presented mild atypia. Large areas of tumour necrosis were seen in four MCAs (Fig. 1f), while the other tumours showed none. Perineural tumour invasion was observed in two MCAs.

Tumour-related extracellular matrix was usually composed of hyalinized eosinophilic collagenous materials (ten cases) (Fig. 1d) with fibrillar morphology. Three MCAs had a myxoid matrix, characterized by loose gelatinous clearbluish substance, and three other tumours showed a mixture of the components described above. Two MCAs presented a scanty tumour matrix. Occurrence of squamous, chondroid and osseous metaplasia was seen in three, one and two cases, respectively. The histological features of our MCAs are summarized in Table 3.

\section{Immunohistochemistry}

Immunohistochemical results are shown in Table 4 and Fig. 2. Staining for c-Myc was observed both in tumour tissue and adjacent normal salivary gland (Fig. 2a). Tumour cells often showed strong staining in the cytoplasm with no apparent nuclear staining (Fig. 2b). Nuclear staining was detected in only a few tumour cells, except in spindle cell MCAs where a large proportion of tumour cells presented nuclear staining. In normal tissues, prominent nuclear staining for c-Myc was 
Fig. 1 Histological characteristics of MCA. a. Multinodular growth pattern. b. Nests of epithelioid MCA cells invading adjacent fat tissue. c. Clear tumour cells displayed in sheets and small lobules. $\mathbf{d}$. Plasmacytoid cells with interspersed hyalinized matrix. e. Spindle cell MCA (left) and reminiscent PA (right) $\mathbf{f}$. Epithelioid tumour cells showing necrosis (bottom left)
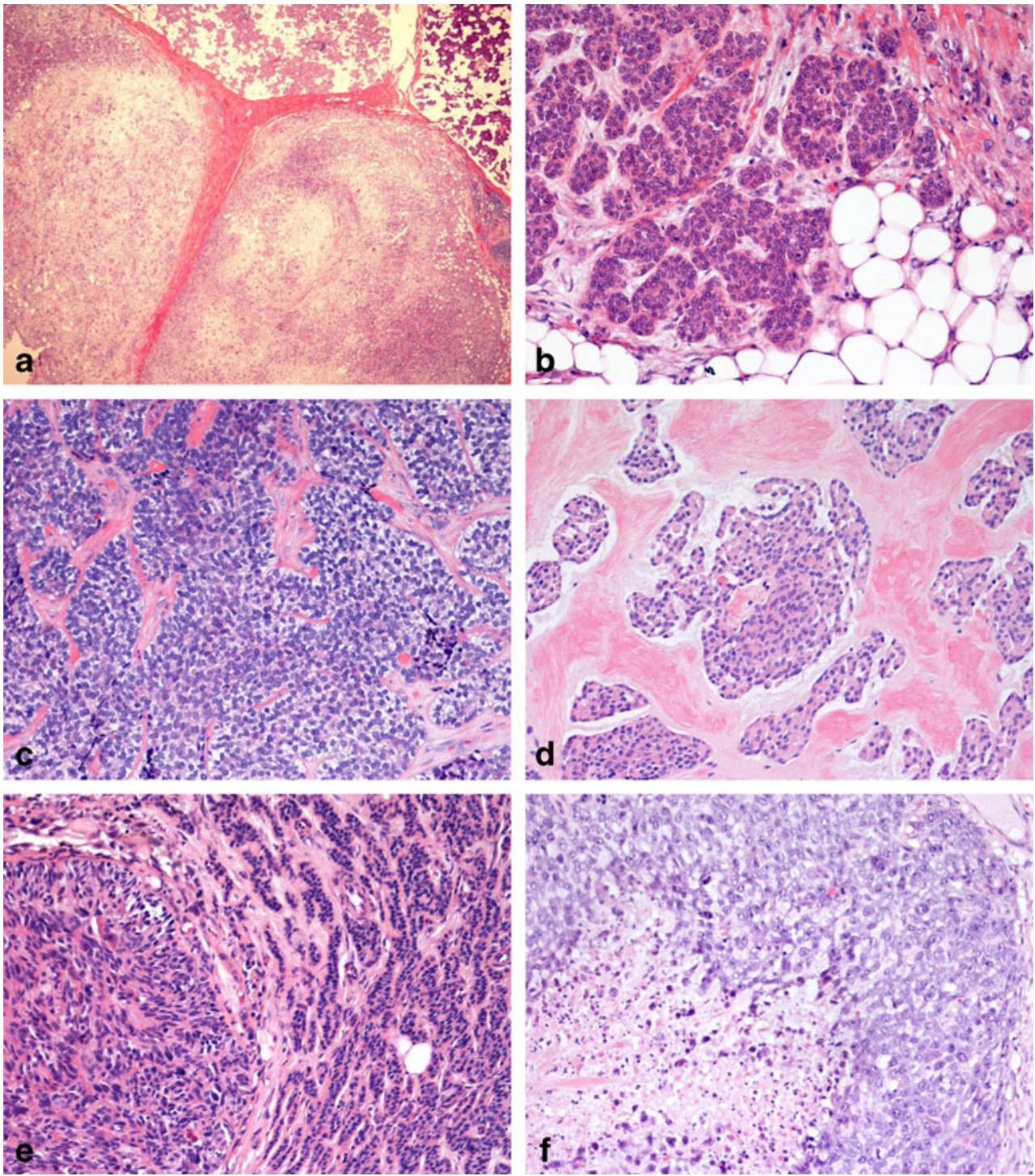

detected in acinar cells while only few myoepithelial cells were positive. Epithelial and myoepithelial cells of normal salivary ducts showed diffuse cytoplasmic staining for cMyc while only a few nuclei were positive.

Staining for Cdk4 was characterized by intense nuclear immunoreactivity in tumour cells, while only very few positive cells were detected in the adjacent normal salivary gland (Fig. 2c). However, the percentage of positive cells in the different MCAs varied considerably (Fig. 2d). Nuclear staining for p21 was seen in some tumour cells, while several MCAs were negative for p21 (Fig. 2e). Adjacent normal salivary gland cells were negative for $\mathrm{p} 21$. Nuclear staining for Cyclin D3 was found in ten MCAs. The number of positive cells varied between individual tumours, but they often had foci with a high number of positive nuclei interspersed with areas with few or no positive nuclei (Fig. 2f). Adjacent normal salivary gland was consistently negative for Cyclin D3.

\section{Statistical analyses}

The results of immunohistochemical staining are summarized in Table 3. In logistic regression analysis, a significant correlation was seen between the intensity of cytoplasmic staining for c-Myc and the occurrence of metastases $(P=0.019)$. A score of 3 for the intensity of cytoplasmic staining for c-Myc was accompanied by a frequency of metastases 24 times higher than for a score of $\leq 2$. No other statistically significant correlations were found between the immunohistochemical results and clinical parameters.

In search of other large series in the literature, we found 48 cases of MCA ex-pleomorphic adenoma with follow-up information, of which 24 patients showed no evidence of disease (NED) and 24 were alive with disease (AWD) or dead of disease (DOD) $[2,4,5,11,12]$. Of the 36 de novo MCA cases, 23 were with NED and 13 DOD or AWD (Table 5). Some cases were lost to follow-up or the authors did not separate de 
Table 3 Histopathological characteristics of 19 cases of myoepithelial carcinoma

\begin{tabular}{|c|c|c|c|c|c|c|c|c|c|}
\hline Case no. & Cell type & Tumour matrix & $\begin{array}{l}\text { History of } \\
\text { benign tumour }\end{array}$ & $\begin{array}{l}\text { Evidence of } \\
\text { benign tumour }\end{array}$ & $\begin{array}{l}\text { Mitosis } \\
\text { score }\end{array}$ & Nuclear atypia & Necrosis & $\begin{array}{l}\text { Nerve } \\
\text { inv }\end{array}$ & $\begin{array}{l}\text { Vascular } \\
\text { inv }\end{array}$ \\
\hline 1 & Epithelioid & Hyalinized & No & No & 3 & 2 & + & - & + \\
\hline 2 & Clear cell & Hyalinized & No & $\mathrm{PA}$ & 1 & 1 & + & - & - \\
\hline 3 & Spindle & Hyalinized & No & No & 1 & 2 & - & - & + \\
\hline 4 & Mixed & Hyalinized & No & $?$ & 1 & 2 & - & - & - \\
\hline 5 & Epithelioid & Hyalinized & No & $\mathrm{PA}$ & 1 & 2 & + & + & - \\
\hline 6 & Epithelioid & Myxoid/hyalinized & Yes & $?$ & 2 & 1 & + & - & - \\
\hline 7 & Spindle & Scanty & No & No & 1 & 2 & - & - & - \\
\hline 8 & Mixed & Myxoid/hyalinized & No & No & 2 & 2 & - & - & - \\
\hline 9 & Clear cell & Hyalinized & Yes & PA & 1 & 2 & - & - & - \\
\hline 10 & Epithelioid & Myxoid/hyalinized & Yes & PA & 2 & 2 & - & - & - \\
\hline 11 & Epithelioid & Hyalinized & No & No & 1 & 2 & - & - & - \\
\hline 12 & Clear cell & Hyalinized & No & No & 3 & 2 & + & + & - \\
\hline 13 & Plasmacytoid & Myxoid & No & No & 2 & 2 & - & - & - \\
\hline 14 & Spindle & Scanty & No & $\mathrm{PA}$ & 3 & 3 & - & - & - \\
\hline 15 & Epithelioid & Hyalinized & No & No & 2 & 2 & - & + & + \\
\hline 16 & Epithelioid & Hyalinized & Yes & $\mathrm{PA}$ & 2 & 2 & + & - & - \\
\hline 17 & Plasmacytoid & Hyalinized & No & No & 1 & 1 & - & - & - \\
\hline 18 & Spindle & Myxoid & No & $\mathrm{PA}$ & 2 & 3 & - & - & - \\
\hline 19 & Epithelioid & Myxoid & No & No & 1 & 1 & - & - & - \\
\hline
\end{tabular}

Mitotic index=1-3; atypia index $=1-3$

$P A$ pleomorphic adenoma, Nerve inv nerve invasion, Vascular inv vascular invasion

Table 4 Immunohistochemical profiles and occurrence of metastases

\begin{tabular}{llllll} 
Case no. & c-Myc & Cyclin D3 & p21-index & Cdk4-index & Metastases \\
\hline 1 & C3N1 & 0 & 2 & 0 & Lungs \\
2 & C2N1 & 1 & 2 & 2 & No \\
3 & C1N1 & 0 & 2 & 2 & No \\
4 & C3N1 & 2 & 2 & 3 & No \\
5 & C2N1 & 2 & 4 & 2 & No \\
6 & C3N1 & 2 & 5 & 3 & Lungs \\
7 & C1N1 & 0 & 2 & 3 & No \\
8 & C1N1 & 1 & 3 & 3 & No \\
9 & C2N1 & 0 & 2 & 3 & No \\
10 & C2N1 & 0 & 2 & 3 & No \\
11 & C2N2 & 1 & 4 & 4 & No \\
12 & C2N2 & 0 & 2 & 4 & No \\
13 & C2N2 & 1 & 4 & 4 & No \\
14 & C2N3 & 0 & 3 & 4 & No \\
15 & C3N1 & 1 & 3 & 4 & No \\
16 & C2N1 & 2 & 3 & 4 & Multiple \\
17 & C2N1 & 1 & 2 & 2 & No \\
18 & C3N0 & 0 & 0 & 2 & Multiple \\
19 & C3N0 & 1 & 2 & 3 & No \\
\hline
\end{tabular}

$C$ cytoplasmic staining; $N$ nuclear staining; index $=\mathrm{i}+\mathrm{e}$, where $i=$ staining intensity and $e=$ extent of staining novo cases from carcinoma ex-pleomorphic adenoma, which we did not include.

\section{Discussion}

This is a collaborative study on 19 cases of MCA. Histopathological characteristics and clinical information of these patients were correlated with the expression of cell cycle proteins including c-Myc, p21, Cdk4 and Cyclin D3. Our followup information suggests that MCA is a malignant tumour with variable behaviour. Of our 19 patients, four (21\%) developed metastases, and three of these (16\%) died of disease. Recurrences developed in seven of our patients $(37 \%)$ and 12 (63\%) had no evidence of disease.

Our results suggest a somewhat worse clinical outcome than in the series reported by Kane et al. 2010 (51 cases/ follow-up available for 18 patients), since these authors found no patients who had died from this disease and $68 \%$ who developed recurrences [3]. On the other hand, our results suggest a better clinical outcome than the series of Savera et al. 2000 ( 25 cases, follow-up available for 17 patients), of which $29 \%$ of patients died of disease, $47 \%$ developed recurrences and $59 \%$ showed no evidence of disease [2]. In our series, this was 37 and $63 \%$, suggesting somewhat better treatment results in our patients (Table 5). In the largest series recently 
Fig. 2 Immunohistochemical staining in MCA. a, b. c-Myc immunoreactivity. Note conspicuous cytoplasmic staining in neoplastic cells and nuclear staining in NSG cells. c. Predominant nuclear positivity in neoplastic cells for cdk4. d. A different area of the same tumour observed in (c), showing a higher number of cdk4-positive cells. e. Strong nuclear p21 staining. f. Foci showing a high number of positive Cyclin D3 nuclei interspersed with areas with few or no positive nuclei
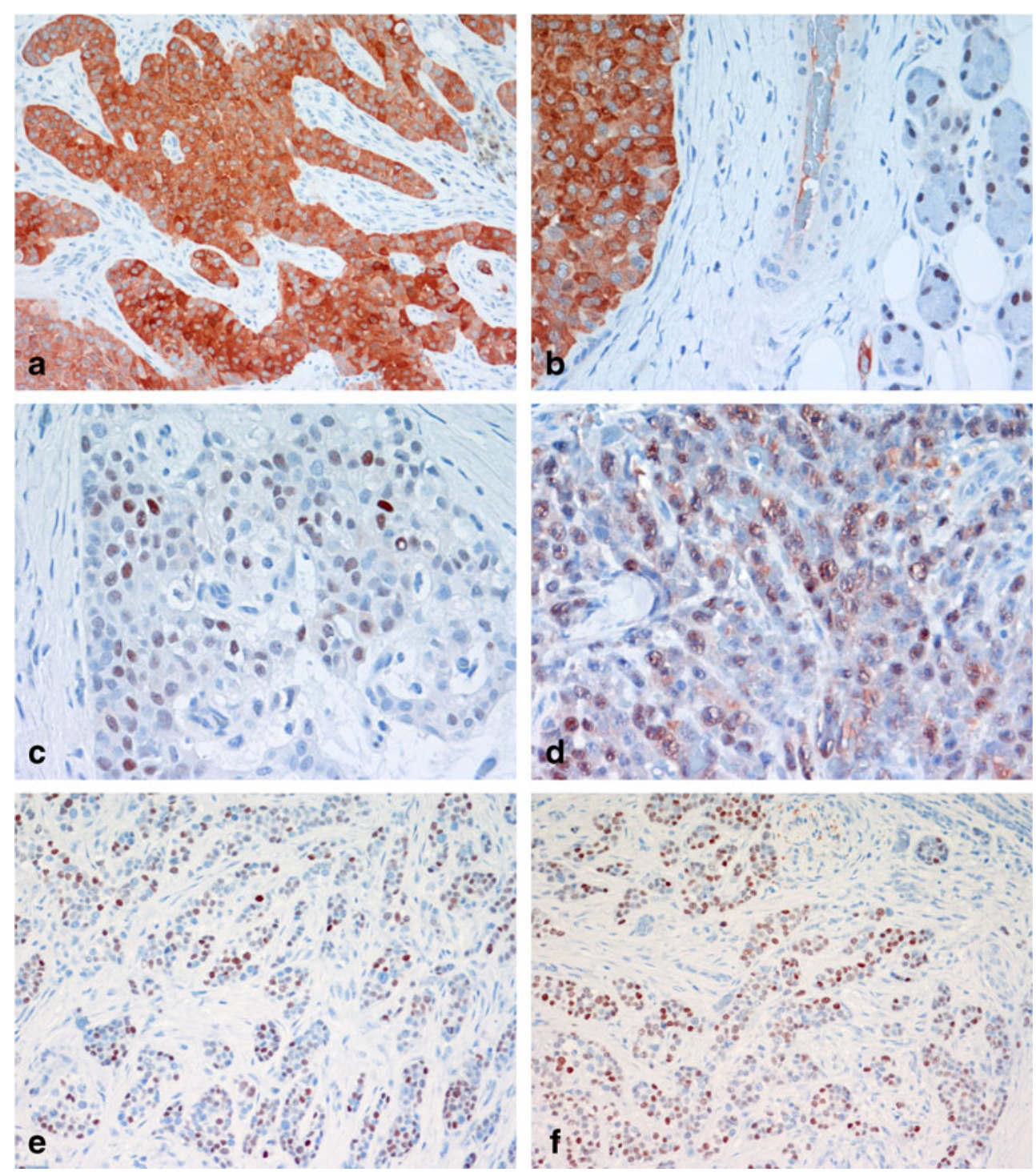

published by Kong et al. (48 cases, follow-up available for 44 patients), nearly one third of the patients developed distant metastasis. [4].

Table 5 Outcome of MCA in literature

\begin{tabular}{lllll}
\hline & $\begin{array}{l}\text { MCA } \\
\text { ex-PA } \\
\text { NED }\end{array}$ & $\begin{array}{l}\text { MCA } \\
\text { ex-PA, } \\
\text { AWD/DOD }\end{array}$ & $\begin{array}{l}\text { MCA } \\
\text { de novo, } \\
\text { NED }\end{array}$ & $\begin{array}{l}\text { MCA } \\
\text { de novo, } \\
\text { AWD/DOD }\end{array}$ \\
\hline Nagao et al. & 4 & 2 & 1 & 2 \\
Savera et al. & 5 & 6 & 2 & 4 \\
Di Palma et al. & 2 & 3 & 2 & 3 \\
Kong et al. & 13 & 13 & 18 & 4 \\
Present study & 2 & 2 & 13 & 2 \\
Total & 26 & 26 & 36 & 15 \\
\hline
\end{tabular}

$P A$ pleomorphic adenoma, $N E D$ no evidence of disease, $A W D$ alive with disease, $D O D$ dead of disease, $N E D$ no evidence of disease
Tumour necrosis was the only histopathological parameter in our MCA cases that correlated with poor disease-free survival. Patients in this group showed 12 times higher occurrence of recurrence, metastasis or death of disease when compared to MCA patients of which the tumour did not show necrosis. Tumour necrosis is easy to evaluate as pathological marker and a well-established marker of poor prognosis in sarcomas, renal cell carcinoma [13-15] as well as a marker of malignancy, e.g. in uterine leiomyoma [16]. A relation between tumour necrosis, cytological atypia, mitotic rate and clinical outcome has been observed before [2, 10], but these parameters were not validated as prognostic markers in MCA. Only recently tumour necrosis has been correlated with reduced disease-free survival in MCA [4, 5]. In our study, only tumour necrosis predicted poor outcome, while cytological atypia and mitotic rate did not. Of all clinical and histopathological parameters in our study, tumour necrosis was the only parameter significantly correlated with disease-free survival 
(DFS). Interestingly, rearrangements involving Ewing's sarcoma breakpoint region 1 (EWSR1) have recently been found in a subset of MCA presenting clear cell morphology and frequent tumour necrosis. The presence of such rearrangements is indicative of worse clinical behaviour [5]. In our study, two of three cases with clear cell morphology exhibited tumour necrosis (Table 3 ).

A wide variety of tumour cell morphologies (clear cell, epithelioid, plasmacytoid, spindle cell) was seen in our MCA cases. Similar to previous studies, the prevalence of any of these cell types did not correlate with clinical outcome. We did not find any histopathological appearance different from those described in previous series, except from stellate cell morphology reported by Kane \& Bagwan [3], which we have not found in our series. This stellate morphology might be a misinterpretation in case of a tumour presenting a mixture of plasmacytoid and spindle cells. Frequent nerve and vascular invasion was reported by Nagao et al. [11], Savera et al. [2] and Kong et al. [4], but we found it in only two cases. The reason for this may be that the previous studies used serial sectioning of their tumours.

The significance of a pre-existing pleomorphic adenoma for the clinical outcome of MCA has been debated in the literature $[2,4,11,12]$. Seven of our cases $(37 \%)$ showed a pre-existing pleomorphic adenoma, and two additional cases (10\%) had appearances suggesting but not conclusive of a pre-existing pleomorphic adenoma. We did not find any difference between the outcome of cases with pre-existing pleomorphic adenoma and de novo MCA cases, which is in agreement with previously published reports $[2,11]$. Nevertheless, together with the cases reported in the literature, our data indicate worse clinical outcome for cases containing a pre-existing pleomorphic adenoma. This differs from the previous report of Di Palma et al. [12] but is in agreement with results reported by Kong et al. [4]. Interestingly, Katabi et al. reported that a carcinoma ex-pleomorphic adenoma MCA recurred more often than other types of carcinoma ex-pleomorphic adenoma [17], and in our series, all cases that developed metastasis also recurred.

Our findings indicate that cytoplasmic expression of c-Myc in MCA cells correlates with the occurrence of metastases. MYC amplification or overexpression is seen in 9 to $48 \%$ of head and neck squamous cell carcinomas [18] and in over $40 \%$ of gastric carcinomas [19]. In addition, evidence suggests that c-Myc not only acts as a transcription factor enhancing translation of many downstream genes but also is involved in chromatin remodelling and ribosome biogenesis and as such implicated in proliferation, differentiation and cell growth [9]. In MCA cells, we detected c-Myc expression in the cytoplasm, but usually not in nuclei. This may imply that in MCA, the role of c-Myc is different from that of a classic transcription factor, perhaps related to the multitude of other processes that can be regulated by c-Myc. However, limitations of semi-quantitation of immunostaining and the limited number of cases preclude definitive conclusions. Additional studies are needed to clarify the role of cytoplasmic c-Myc protein in MCA. In view of our present results on c-Myc, we note that copy number gain has been found in MCA in proximity to the MYC gene at 8q24.21 [20].

Overexpression of p21, cdk4 and Cyclin D3 was seen in a few of our cases but no significant correlations were established. This does not preclude a cell cycle stimulating effect of overexpression of these molecules in individual cases.

Disruption of the retinoblastoma $(\mathrm{Rb})$ pathway has been reported in many types of salivary gland tumour, including MCA [21]. Using immunohistochemistry, Vekony et al. [22] observed increased expression of p16/ARF in MCA compared to normal salivary gland. MCA also shows overexpression of p53 [11, 22]. We hypothesize that malignant transformation of myoepithelial cells may require deregulation of the p16/ARF pathway and inactivation of p53. The Rb, p53, p16 and c-Myc pathways may be involved in regulation of the cell cycle during pathogenesis of MCA.

In conclusion, clinical behaviour in MCA is variable and identification of prognostic factors has been challenging. In our series of MCA, the presence of tumour necrosis correlated with worse disease-free survival, while a pre-existing pleomorphic adenoma did not influence clinical outcome.

Acknowledgments The authors acknowledge financial support from the Finnish Cancer Society, Finska Läkaresällskapet and the Maritza and Reino Salonen Foundation. The technical assistance of Ms. Eija Heiliö and Ms. Tuija Järvinen is kindly acknowledged.

\section{Compliance with ethical standards}

Conflict of interest The authors declare that they have no competing interests.

\section{References}

1. Skalova A, Jakel K (2005) Myoepithelial carcinoma. In: Barnes L, Eveson J, Reichart P, Sidransky D (eds) World health organization classification of head and neck tumours. IARC, Lyon, pp 240-241

2. Savera AT, Sloman A, Huvos AG, Klimstra DS (2000) Myoepithelial carcinoma of the salivary glands: a clinicopathologic study of 25 patients. Am J Surg Pathol 24:761-774

3. Kane SV, Bagwan IN (2010) Myoepithelial carcinoma of the salivary glands: a clinicopathologic study of 51 cases in a tertiary cancer center. Arch Otolaryngol Head Neck Surg 136:702-712. doi:10.1001/archoto.2010.104

4. Kong M, Drill EN, Morris L, West L, Klimstra D, Gonen M, Ghossein R, Katabi N (2015) Prognostic factors in myoepithelial carcinoma of salivary glands: a clinicopathologic study of 48 cases. Am J Surg Pathol 39(7):931-938. doi:10.1097/PAS. 0000000000000452, PubMed

5. Skálová A, Weinreb I, Hyrcza M, Simpson RH, Laco J, Agaimy A, Vazmitel M, Majewska H, Vanecek T, Talarčik P, Manajlovic S, Losito SN, Šteiner P, Klimkova A, Michal M (2015) Clear cell myoepithelial carcinoma of salivary glands showing EWSR1 
rearrangement: molecular analysis of 94 salivary gland carcinomas with prominent clear cell component. Am J Surg Pathol 39(3):338 348. doi:10.1097/PAS.0000000000000364, PubMed

6. Weinberg R (2007) pRB and control of the cell cycle clock. In: Weinberg R (ed) The biology of cancer, firstth edn. Garland Science, New York, pp 255-306

7. Malumbres M, Barbacid M (2009) Cell cycle, CDKs and cancer: a changing paradigm. Nat Rev Cancer 9:153-166. doi:10.1038/ $\operatorname{nrc} 2602$

8. Dominguez Sola D, Ying CY, Grandori C, Ruggiero L, Chen B, Li M, Galloway DA, Gu W, Gautier J, Dalla Favera R (2007) Nontranscriptional control of DNA replication by c-Myc. Nature 448:445-451. doi:10.1038/nature05953

9. Van Riggelen J, Yetil A, Felsher DW (2010) MYC as a regulator of ribosome biogenesis and protein synthesis. Nat Rev Cancer 10: 301-309. doi:10.1038/nrc2819

10. Eilers M, Eisenman RN (2008) Myc's broad reach. Genes Dev 22: 2755-2766. doi:10.1101/gad.1712408

11. Nagao T, Sugano I, Ishida Y, Tajima Y, Matsuzaki O, Konno A, Kondo Y, Nagao K (1998) Salivary gland malignant myoepithelioma: a clinicopathologic and immunohistochemical study of ten cases. Cancer 83:1292-1299

12. Di Palma S, Guzzo M (1993) Malignant myoepithelioma of salivary glands: clinicopathological features of ten cases. Virchows Arch A Pathol Anat Histopathol 423:389-396

13. Cai C, Dehner LP, El-Mofty SK (2013) In myofibroblastic sarcomas of the head and neck, mitotic activity and necrosis define grade: a case study and literature review. Virchows Arch 463(6):827-836. doi:10.1007/s00428-013-1494-1, Epub 2013 Oct 17. Review. PubMed

14. Pichler M, Hutterer GC, Chromecki TF, Pummer K, Mannweiler S, Zigeuner R (2013) Presence and extent of histological tumour necrosis is an adverse prognostic factor in papillary type 1 but not in papillary type 2 renal cell carcinoma. Histopathology 62:219228

15. Lohse CM, Cheville JC (2005) A review of prognostic pathologic features and algorithms for patients treated surgically for renal cell carcinoma. Clin Lab Med 25:433-464

16. Yanai H, Mani Y, Notohara K, Takada S, Yoshino T (2010) Uterine leiomyosarcoma arising in leiomyoma: Clinicopathological study of four cases and literature review. Pathol Int 60:506-509

17. Katabi N, Gomez D, Klimstra DS, Carlson DL, Lee N, Ghossein R (2010) Prognostic factors of recurrence in salivary carcinoma ex pleomorphic adenoma, with emphasis on the carcinoma histologic subtype: a clinicopathologic study of 43 cases. Hum Pathol 41:927934. doi:10.1016/j.humpath.2009.12.011

18. Klein JD, Grandis JR (2010) The molecular pathogenesis of head and neck cancer. Cancer Biol Ther 9:1-7

19. Calcagno DQ, Leal MF, Assumpcao PP, Smith MA, Burbano RR (2008) MYC and gastric adenocarcinoma carcinogenesis. World J Gastroenterol 14:5962-5968

20. Vékony H, Röser K, Löning T, Ylstra B, Meijer GA, Van Wieringen WN et al (2009) Copy number gain at 8q12.1-q22.1 is associated with a malignant tumor phenotype in salivary gland myoepitheliomas. Genes Chromosomes Cancer 48:202-212

21. Etges A, Nunes FD, Ribeiro KC, Araujo VC (2004) Immunohistochemical expression of retinoblastoma pathway proteins in normal salivary glands and in salivary gland tumours. Oral Oncol 40:326-331

22. Vekony H, Roser K, Loning T, Raaphorst FM, Leemans CR, Van Der Waal I, Bloemena E (2008) Deregulated expression of p16INK4a and p53 pathway members in benign and malignant myoepithelial tumours of the salivary glands. Histopathology 53: 658-666. doi:10.1111/j.1365-2559.2008.03184.x 